\title{
Vertical Extrapolation of Wind Speeds Under a Neutral Atmosphere and Evaluation of the Wind Energy Potential on Different Sites in Guinea
}

\author{
Kalil Pierre Mathos 1, 2, *, Hagninou Elagnon Venance Donnou ${ }^{1}$, Clément Adéyèmi Kouchadé1, \\ Basile Bruno Kounouhewa ${ }^{1}$ \\ ${ }^{1}$ Laboratory of Radiation Physics (LPR), University of Abomey-Calavi, Cotonou, Benin \\ ${ }^{2}$ Institute of Mathematics and Physical Sciences (IMSP), University of Abomey-Calavi, Porto-Novo, Benin
}

Email address:

kalilpmathos@gmail.com (K. P. Mathos),donhelv@yahoo.fr (H. E. V. Donnou), ckouchade@yahoo.fr (C. A. Kouchadé),

kbbasile@gmail.com (B. B. Kounouhewa)

${ }^{*}$ Corresponding author

To cite this article:

Kalil Pierre Mathos, Hagninou Elagnon Venance Donnou, Clément Adéyèmi Kouchadé, Basile Bruno Kounouhewa. Vertical Extrapolation of Wind Speeds Under a Neutral Atmosphere and Evaluation of the Wind Energy Potential on Different Sites in Guinea. American Journal of Energy Engineering. Vol. 8, No. 1, 2020, pp. 9-17. doi: 10.11648/j.ajee.20200801.12

Received: April 30, 2020; Accepted: June 5, 2020; Published: June 17, 2020

\begin{abstract}
This study has been focused on the vertical profile determination of the winds under a neutral atmosphere in order to assess of the wind power density at three sites in Guinea. The power law has been used as an extrapolation model for wind speed. The Weibull function has been used to estimate the wind power density. The satellite data at $10 \mathrm{~m}$ above the ground recorded during the period from January 2001 to December 2015 on the sites of Conakry, Mamou and N'zérékoré sites were used. The results indicate that the Conakry site is the windiest of the three study sites with an average speed estimated at $2.83 \mathrm{~m} . \mathrm{s}^{-1}$ at $10 \mathrm{~m}$ and $4.23 \mathrm{~m} . \mathrm{s}^{-1}$ at $100 \mathrm{~m}$ above the ground. The form parameter $\mathrm{k}$ of Weibull varies from 1 to 1.8 and the scale parameter $\mathrm{c}$ from 1.5 to $6 \mathrm{~m} \cdot \mathrm{s}^{-1}$ and are both increasing functions of altitude. Finally, the quantities of energy obtained at the three sites reveal that only the Conakry site could be suitable for the installation of small wind turbines for the wind energy production. The average annual density is estimated at $45.77 \mathrm{~W} \cdot \mathrm{m}^{-2}$ at $10 \mathrm{~m} ; 85.62 \mathrm{~W} \cdot \mathrm{m}^{-2}$ at $50 \mathrm{~m}$ and $113.31 \mathrm{~W} \cdot \mathrm{m}^{-2}$ at $100 \mathrm{~m}$. On the Mamou and N'zérékoré sites, the pumping water from multi-blade wind turbines could be considered.
\end{abstract}

Keywords: Vertical Profile of Winds, Power Law, Weibull Function, Wind Power, Wind Turbine

\section{Introduction}

Access to energy is a major challenge for the socio-economic well-being of populations. With the progressive depletion of traditional energy sources and their impact on the environment, it is imperative to reconcile the development strategies of the energy sector with the environment. There are therefore prospects for the renewable energies which are today essential in the energy mix. Among these sources, the wind power is enough promising and the global installed capacity is constantly increasing (from 23,900 in 2001 to $539,581 \mathrm{MW}$ in 2017) [1]. It therefore deserves to be exploited, especially in developing countries. For a better exploitation of wind energy on a site, the availability of wind data at an altitude higher than $10 \mathrm{~m}$ above the ground is important for the assessment of potential. Unfortunately, the measurement heights of meteorological towers $(10 \mathrm{~m}$ above the sea level) are generally lower than those of the modern turbines which sometimes exceed $100 \mathrm{~m}$ above the ground.

To cope with this difficulty, there are simple approaches to extrapolating wind speed, based on Monin-Obukhov theory and applicable only in the surface layer $[2,3]$. It is the power and logarithmic laws which give a better profile of the wind speed at altitude and developed by several authors such as [4-14]. Elkinton et al. [4] show that their predictions in altitude are identical, although on certain sites, one model may be better than another. For Emeis [6], under ideal conditions for wind energy conversion, the power law allows to estimate more easily the wind profile in the surface layer. Lackner et al. [15] founded that the power law is more suitable for giving a realistic wind profile 
to that of the logarithmic law. In the studies of Elkinton et al. [5] reported by Okorie et al. [16], the authors believe that the profile of winds in altitude obtained by the power law is more representative on a site. In view of these different works, the use of the power law is therefore more appropriate. It requires the knowledge of the shear coefficient which depends on the nature of the ground and the atmospheric stability of each sites [17, 18]. Thus, a shear model is necessary to extrapolate the wind resource observed from the lower heights available at the height of the turbine hub. In the literature several values of wind shear are proposed according to the nature of the ground and for neutral atmospheric conditions [19,20].

In Guinea and at the three study sites (Conakry, Mamou, N'zérékoré), the wind speeds at an altitude above $10 \mathrm{~m}$ are not accessible except the wind data at a height of $10 \mathrm{~m}$ used in this study. To compensate for this lack of data on wind in altitude, the power law model under a neutral atmosphere has been used in this study to estimate the wind speed between 10 and $100 \mathrm{~m}$ altitude and assess the available wind potential. To achieve of this goal, some characteristics of the average wind speed on the three sites have been in first determined. Then, the extrapolation of the wind speeds from $10 \mathrm{~m}$ to $100 \mathrm{~m}$ has been carried out. Finally the wind power density has been evaluated in order to deduce from this study the sites capable to shelter wind projects.

\section{Material and Methods}

\subsection{Presentation of Study Area and the Data Used}

Guinea is located in the West Africa and covers an area of
$245,857 \mathrm{~km}^{2}$. It is a coastal country with $300 \mathrm{~km}$ of Atlantic coastline, halfway between the equator and the Tropic of Cancer (between 705 and $12^{\circ} 51$ north latitude and $7^{\circ} 30$ and $15^{\circ} 10$ west longitude). It is bounded in the west by the Atlantic Ocean, in the south by Sierra Leone and Liberia, in the east by Côte d'Ivoire and Mali and in the north by Guinea Bissau, Senegal and Mali [21]. The country is characterized by significant climatic differences, due in large part of the relief variety. The sub-Guinean tropical climate in Lower Guinea has an average temperatures of order from $23^{\circ} \mathrm{C}$ to $25^{\circ} \mathrm{C}$, a significant rainfall between 2,100 and $5,000 \mathrm{~mm}$, with a monthly maximum of more than $1,000 \mathrm{~mm}$ recorded in August. In the tropical mountain climate of the Foutanien type, in average Guinea, the two seasons are of approximately equal duration and the rainfall varies from $1600 \mathrm{~mm}$ to $2000 \mathrm{~mm}$. Given the altitude, the temperatures are lower at night and during the dry season. The dry sub-Sudanian tropical climate of Upper Guinea totalizes a lower amount of rain: 1100 to $1800 \mathrm{~mm}$ and raised temperatures varying between $26^{\circ} \mathrm{C}$ and $27^{\circ} \mathrm{C}$ due to the influence of continentality. From December to February, the influence of the harmattan is noticed. The subequatorial climate of Forest Guinea is characterized by a long rainy season from eight to ten months (1600 to $2800 \mathrm{~mm}$ of rain) and the average annual temperatures of order from $24^{\circ}$ to $26^{\circ} \mathrm{C}$ [22]. Three areas were selected for this study, namely Conakry, Mamou, N'zérékoré. Figure 1 gives an overview of their geographic location in Guinea and Africa.

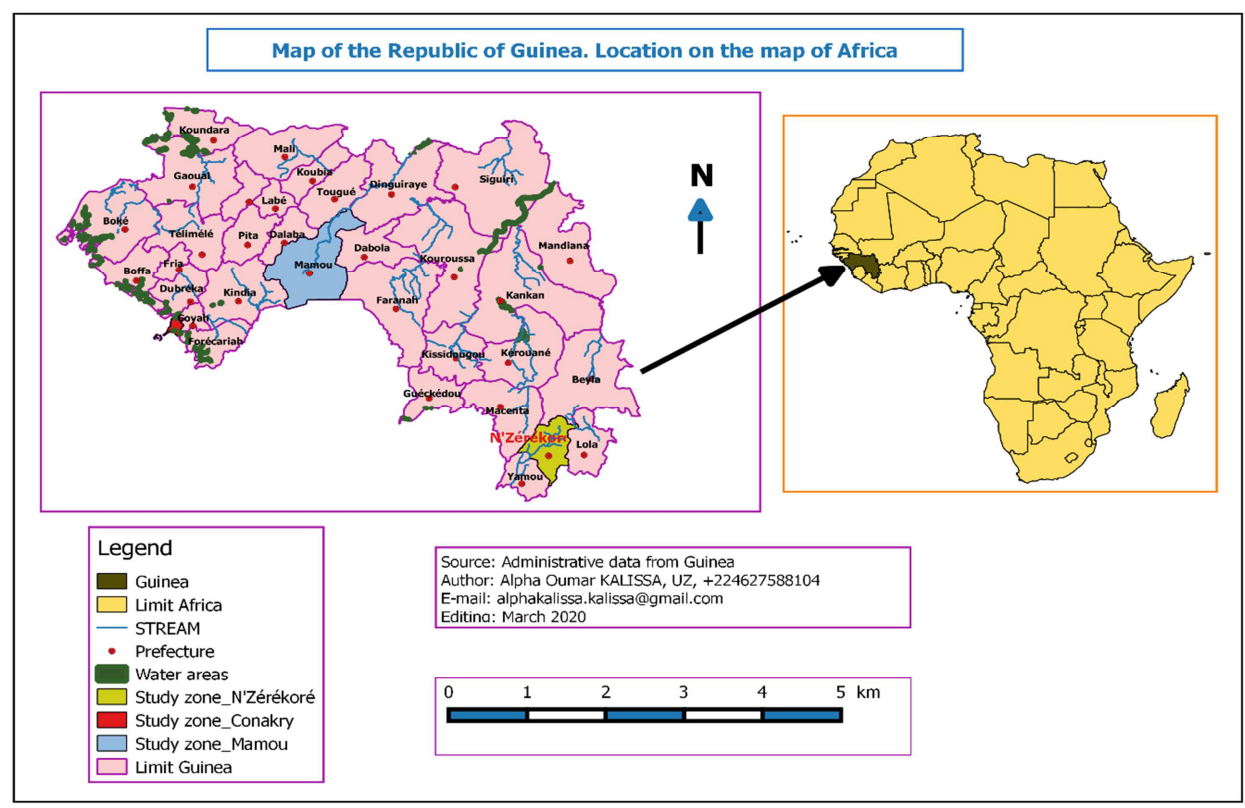

Figure 1. Geographical situation of the study area. Location on the map of Africa.

The satellite data of the daily average wind speed recorded and provided by the Guinean national weather direction covering the period from January 2001 to December 2015 have been used in this study. In Table 1, the characteristics of the measurement sites are presented.
Table 1. Characteristics of measurement sites.

\begin{tabular}{llll}
\hline Site & Longitude & Latitude & Height \\
\hline Conakry & $13^{\circ} 34^{\prime} \mathrm{O}$ & $9^{\circ} 34^{\prime} \mathrm{N}$ & $10 \mathrm{~m}$ \\
Mamou & $12^{\circ} 05^{\prime} \mathrm{O}$ & $10^{\circ} 22^{\prime} \mathrm{N}$ & $10 \mathrm{~m}$ \\
N'zérékoré & $8^{\circ} 783^{\prime} \mathrm{O}$ & $7^{\circ} 75^{\prime} \mathrm{N}$ & $10 \mathrm{~m}$ \\
\hline
\end{tabular}


The data collected has been processed using Matlab R2013a software (8.1.0.604) for the study.

\subsection{Methods}

\subsubsection{Power Law}

In the studies carried out by Justus et al. [23], the authors preferred to equate the increasing of the wind speed $\left(\mathrm{V}_{\mathrm{h}}\right)$ with the height $\left(Z_{h}\right)$ in the surface layer at a power law. This law was which is a function of the wind shear coefficient is proposed by Hellman [24] and reported in the works of Spera and Richards, Kulkarni and Huang, Gualtieri and Secci [25, 26, 27]:

$$
\frac{\mathrm{v}_{\mathrm{h}}}{\mathrm{v}_{1}}=\left(\frac{\mathrm{Z}_{\mathrm{h}}}{\mathrm{z}_{1}}\right)^{\alpha}
$$

This law only depends on a single parameter called the wind shear coefficient. Its value depends on several factors such as the characteristics of the ground and the atmospheric stability. From equation (1), the coefficient $\alpha$ can be determined through the equation (2):

$$
\alpha=\frac{\ln \left(V_{h}\right)-\ln \left(V_{1}\right)}{\ln \left(Z_{h}\right)-\ln \left(z_{1}\right)}
$$

$\mathrm{V}_{1}$ is the wind speed at $10 \mathrm{~m}$ above the ground, $\mathrm{Z}_{1}$ is an altitude of $10 \mathrm{~m}$. The values of the wind shear coefficient are proposed in the bibliography by certain authors according to the nature of the ground (Table 2).

Table 2. Value of the wind shear coefficient for different types of terrain (Bilal [28]).

\begin{tabular}{lll}
\hline Roughness class & Type of land & $\boldsymbol{\alpha}$ \\
\hline 1 & Large bodies of water (Oceans, seas, lakes) & 0.166 \\
2 & Flat grassland meadows without trees or buildings & 0.182 \\
3 & Flat or slightly wavy countryside base with obstacles & 0.202 \\
4 & Countryside with high crops (mils, corn, small fruit trees) & 0.229 \\
5 & Dense hedgerow, orchards, small woods, suburbs \\
6 & Urban areas, woods and forests & 0.240 \\
\hline
\end{tabular}

For the Conakry, Mamou and N'zérékoré sites, the values of $\alpha$ used are respectively equal to $0.166 ; 0.182$ and 0.226 .

\subsubsection{Wind Power Density}

To assess the wind resource available at a given site, the determination of the wind power density is required. It is given by Fagbenle et al., Akinsanola et al. [29, 30]:

$$
\mathrm{P}=\frac{1}{2} \rho c^{3} \Gamma\left(1+\frac{3}{k}\right)
$$

With $\mathrm{c}$ and $\mathrm{k}$ the parameters of the Weibull distribution. $\mathrm{c}$ is the scale parameter $\left(\mathrm{m}_{\mathrm{s}} \mathrm{s}^{-1}\right)$ and $\mathrm{k}$ the shape parameter, $\rho$ is the density of the flow $\left(\mathrm{kg} . \mathrm{m}^{-3}\right)$.. They are given by Justus et al., Didane et al. [23, 31]:

$$
\mathrm{k}=0.83(\overline{\mathrm{V}})^{0.5}
$$

$\overline{\mathrm{V}}$ is the average wind $\left(\mathrm{m} \cdot \mathrm{s}^{-1}\right)$

$$
\mathrm{C}=\frac{\bar{V}}{\Gamma\left(1+\frac{1}{k}\right)}
$$

$\Gamma$ is the gamma function. It is expressed as follows:

$$
\Gamma=\int_{0}^{\infty} \exp (-\mathrm{t}) \mathrm{t}^{\mathrm{x}-1} \mathrm{dt}
$$

\section{Results and Discussions}

\subsection{Daily and Monthly Variation of Wind Speed}

In Figure 2 the daily variation in wind speed is presented.
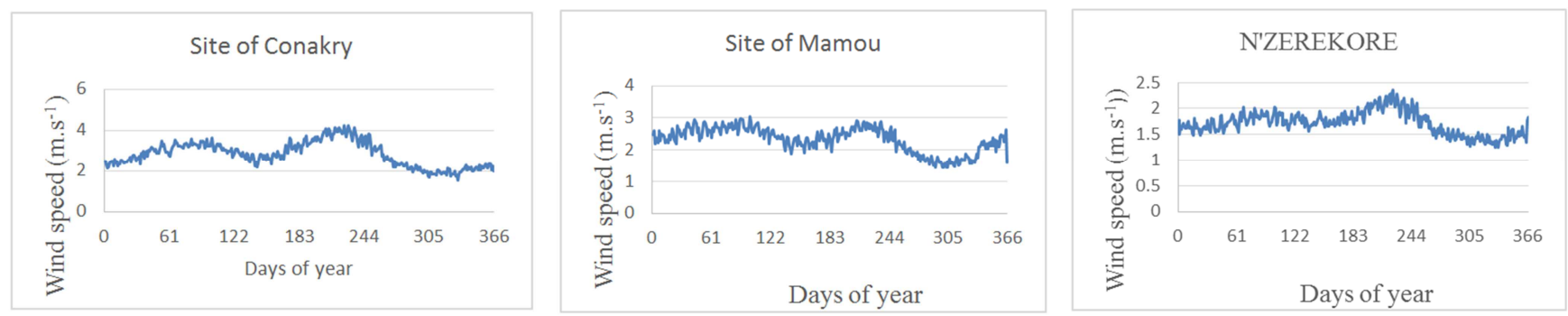

Figure 2. Daily variation of wind speeds during the year

The analysis in Figure 2 shows two peaks of the wind speed during the year at the Conakry site. A first peak is recorded on April 6 and evaluated at $3.58 \mathrm{~m} . \mathrm{s}^{-1}$. The second peak, more pronounced is observed on August 13 and estimated at 4.2 $\mathrm{m} . \mathrm{s}^{-1}$. The lowest value recorded during the year is estimated at $1.53 \mathrm{~m} . \mathrm{s}^{-1}$ on November 28 . The average annual speed observed in Conakry is estimated at $2.83 \mathrm{~m} . \mathrm{s}^{-1}$. On the Mamou site we observe three peaks. A first peak evaluated at 3.04 $\mathrm{m} . \mathrm{s}^{-1}$ on April 10, a second peak obtained on July 29 and evaluated at $2.92 \mathrm{~m} . \mathrm{s}^{-1}$ and the third peak on December 30 with a speed of $2.64 \mathrm{~m} . \mathrm{s}^{-1}$. The low value recorded is obtained on October $31\left(1.44 \mathrm{~m} \cdot \mathrm{s}^{-1}\right)$ on this site. The average annual 
speed observed in Mamou is estimated at $2.31 \mathrm{~m} . \mathrm{s}^{-1}$. On the N'zérékoré site one peak has been recorded during the year. It is observed on August 12 with a value of $2.36 \mathrm{~m} . \mathrm{s}^{-1}$. The lowest value of wind speed is recorded on November 30 (1.25
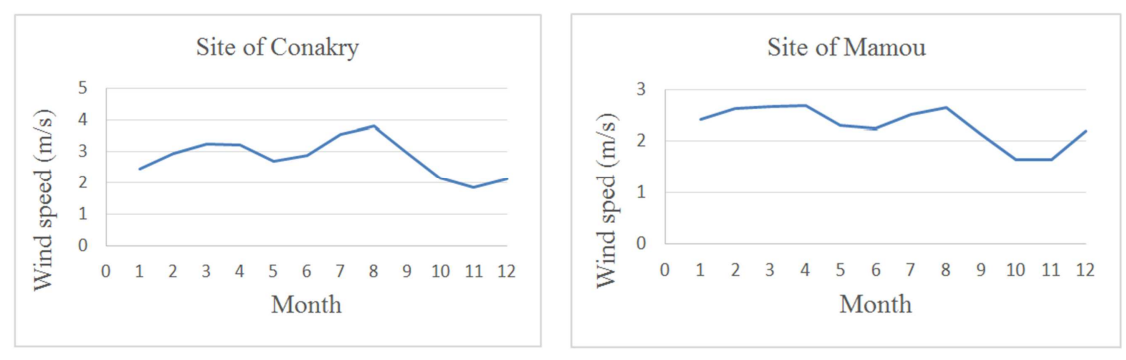

Figure 3. Monthly variation of the wind speed. $\mathrm{m} . \mathrm{s}^{-1}$ ) and the average annual speed is estimated at $1.72 \mathrm{~m} . \mathrm{s}^{-1}$.

In Figure 3 the monthly variation of the wind speed is presented for the three study sites.
On the site of Conakry the highest values of the wind speed are observed during the months of March, April, July and August. The values obtained are respectively evaluated at 3.23 $\mathrm{m} . \mathrm{s}^{-1} ; 3.2 \mathrm{~m} . \mathrm{s}^{-1} ; 3.55 \mathrm{~m} . \mathrm{s}^{-1}$ and $3.81 \mathrm{~m} . \mathrm{s}^{-1}$. The least windy months of the year are October, November and December and the wind speeds are respectively estimated at $2.15 \mathrm{~m} . \mathrm{s}^{-1} ; 1.86$ $\mathrm{m} . \mathrm{s}^{-1}$ and $2.13 \mathrm{~m} . \mathrm{s}^{-1}$. On the site of Mamou, the months of February, March, April and August are the windiest with values evaluated respectively at $2.64 \mathrm{~m} . \mathrm{s}^{-1 ;} 2.68 \mathrm{~m} . \mathrm{s}^{-1} ; 2.7$ $\mathrm{m} . \mathrm{s}^{-1} ; 2.65 \mathrm{~m} . \mathrm{s}^{-1}$ while in October and November the lowest values are observed $\left(1.63 \mathrm{~m} . \mathrm{s}^{-1 ;} 1.64 \mathrm{~m} . \mathrm{s}^{-1}\right)$. On the site of N'zérékoré, the month of August is the windiest $\left(2.07{\left.\mathrm{~m} . \mathrm{s}^{-1}\right)}^{-1}\right.$ and the month of November the least windy $\left(1.38 \mathrm{~m} \cdot \mathrm{s}^{-1}\right)$.

On the three sites studied, Conakry is the windiest site with the highest values of wind speed.

\subsection{Vertical Wind Profile}

In Figures 4, 5 and 6 the vertical wind profile obtained at the Conakry, Mamou and N'zérékoré sites using the power law method have been presented. In Conakry, at the months of January, February and March, the average daily wind speed varies respectively from $3.5 \mathrm{~m} . \mathrm{s}^{-1}$ obtained in January to 4.7 $\mathrm{m} . \mathrm{s}^{-1}$ observed in March at $100 \mathrm{~m}$ above the ground. During
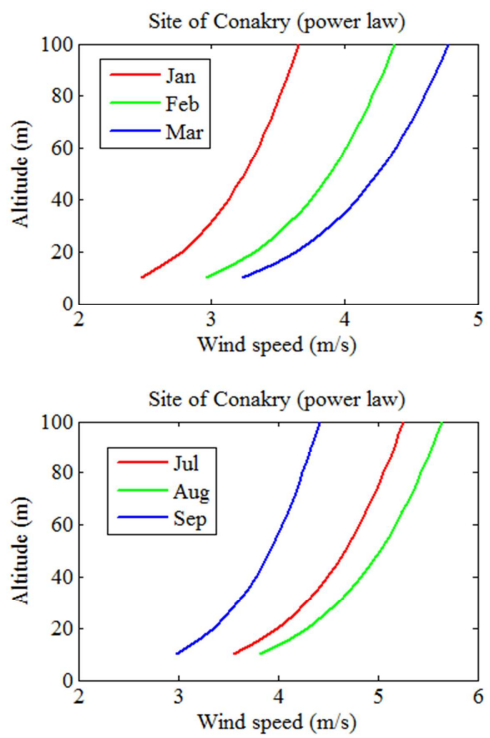

the period from April to June the winds reached $4.75 \mathrm{~m} . \mathrm{s}^{-1}$ in April at $100 \mathrm{~m}$ altitude. Between July and September the highest wind speeds recorded during the year are observed during this period and vary from $4.2 \mathrm{~m} . \mathrm{s}^{-1}$ in September to 5.5 $\mathrm{m} . \mathrm{s}^{-1}$ in August. From October to December the winds are lower at $100 \mathrm{~m}$ altitude and vary from $2.75 \mathrm{~m} . \mathrm{s}^{-1}$ (November) to $3.25 \mathrm{~m} . \mathrm{s}^{-1}$ (October). The average annual speed at $100 \mathrm{~m}$ is around $4.23 \mathrm{~m} \cdot \mathrm{s}^{-1}$. On the site of Mamou during the period from January to June, the average daily wind speeds vary from $3.4 \mathrm{~m} . \mathrm{s}^{-1}$ in June to $4.1 \mathrm{~m} . \mathrm{s}^{-1}$ in April at $100 \mathrm{~m}$ above the ground. From July to December the wind speeds vary from 2.5 $\mathrm{m} . \mathrm{s}^{-1}$ in October-November to $4 \mathrm{~m} . \mathrm{s}^{-1}$ in August. The lowest winds are recorded from October to November and the highest in April and August. The average annual speed at $100 \mathrm{~m}$ is estimated at $3.50 \mathrm{~m} . \mathrm{s}^{-1}$. In N'zérékoré, the wind speeds observed during the year do not vary much from one month to another. The windiest periods are August $\left(3.8 \mathrm{~m} . \mathrm{s}^{-1}\right)$ and the least windy are November $\left(2.5 \mathrm{~m} . \mathrm{s}^{-1}\right)$. The average annual speed at $100 \mathrm{~m}$ is estimated at $3.19 \mathrm{~m} . \mathrm{s}^{-1}$. Moreover whatever the site, a significant variation of the wind near the ground is noted and would be due to the effect of roughness and obstacles encountered on the ground and which decreases with altitude.
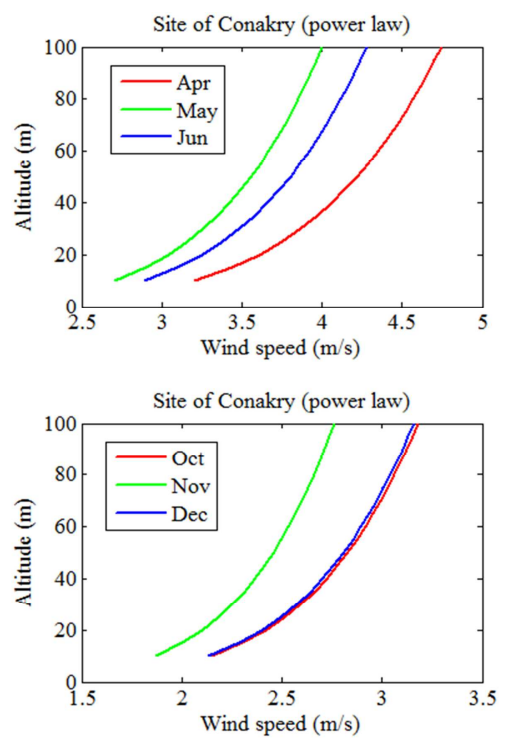

Figure 4. Wind speed variation in function of altitude in Conakry. 

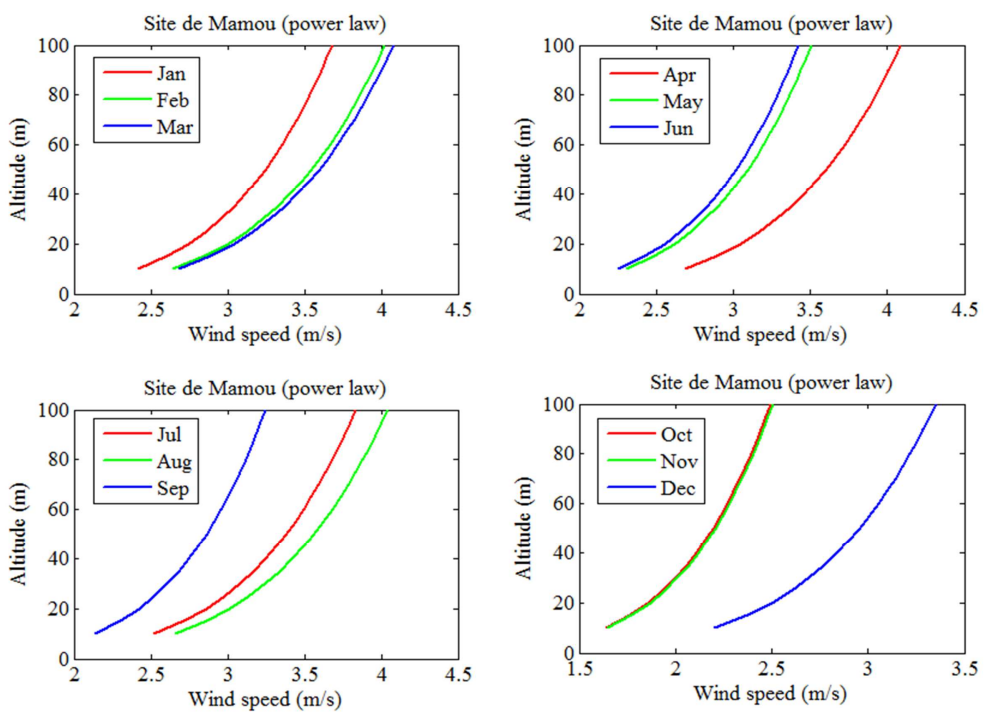

Figure 5. Wind speed variation in function of altitude in Mamou.
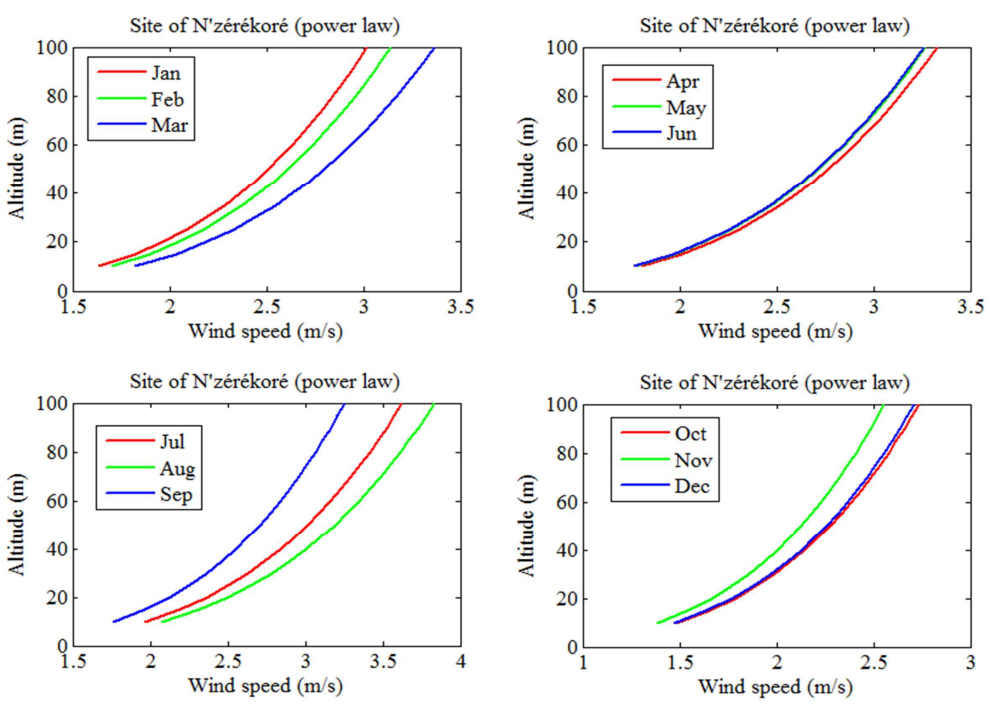

Figure 6. Wind speed variation in function of altitude in N'zérékoré.

\subsection{Variation of the Wind Energy}

In Figure 7 the variations of the Weibull parameters $\mathrm{k}$ and $\mathrm{c}$ are presented.
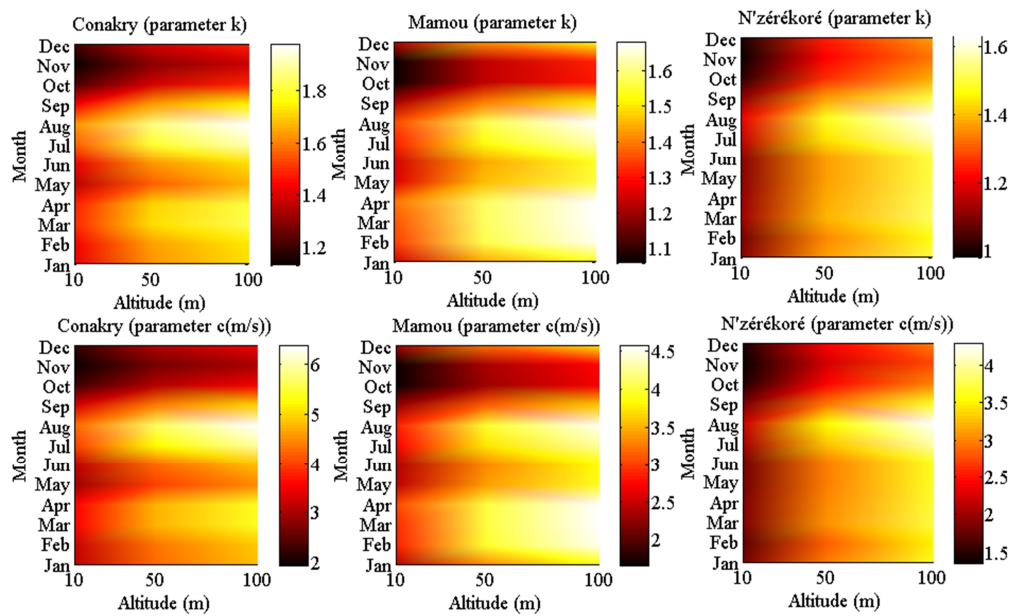

Figure 7. Variation of the parameters $k$ and $c$ in function of the altitude. 
The two Weibull parameters namely the scale parameter c and the form parameter $\mathrm{k}$ are an increasing function of the altitude. The scale parameter c varies more quickly depending on the altitude than the parameter k. In Conakry, $\mathrm{k}$ varies from 1.2 at $10 \mathrm{~m}$ in November-December to 1.8 at $100 \mathrm{~m}$ observed in August. In Mamou it varies at $10 \mathrm{~m}$ from 1.1 (October-November) to $1.6(100 \mathrm{~m})$ during the months of February to April and August. In N'zérékoré, $\mathrm{k}$ is between 1 (October to December) and 1.6 (August) from $10 \mathrm{~m}$ to $100 \mathrm{~m}$. The highest values of the parameter $\mathrm{k}$ are therefore observed during the windiest months and the lowest during the least windy period. The scale parameter $\mathrm{c}$ varies from $2 \mathrm{~m} \cdot \mathrm{s}^{-1}$ (November-December) to $6 \mathrm{~m} \cdot \mathrm{s}^{-1}$ (August) between 10 and
$100 \mathrm{~m}$. In Mamou, at $100 \mathrm{~m}$ above the ground, the highest value of $\mathrm{c}$ is estimated at $4.5 \mathrm{~m} . \mathrm{s}^{-1}$ during the period from February to April and in August. In N'zérékoré, the highest scale parameter is evaluated at $4 \mathrm{~m} \cdot \mathrm{s}^{-1}$ at $100 \mathrm{~m}$ and obtained in August. We can therefore say that the higher the Weibull parameters are over a period the more the wind speeds are also it over the same period. These results are therefore in agreement with the studies of Ajavon et al. [32] which stipulates that the Weibull parameters increase with the frequency of the wind.

In Figure 8, the monthly wind power densities that are observed for the three sites at altitudes $10 \mathrm{~m}, 50 \mathrm{~m}$ and $100 \mathrm{~m}$ are presented.
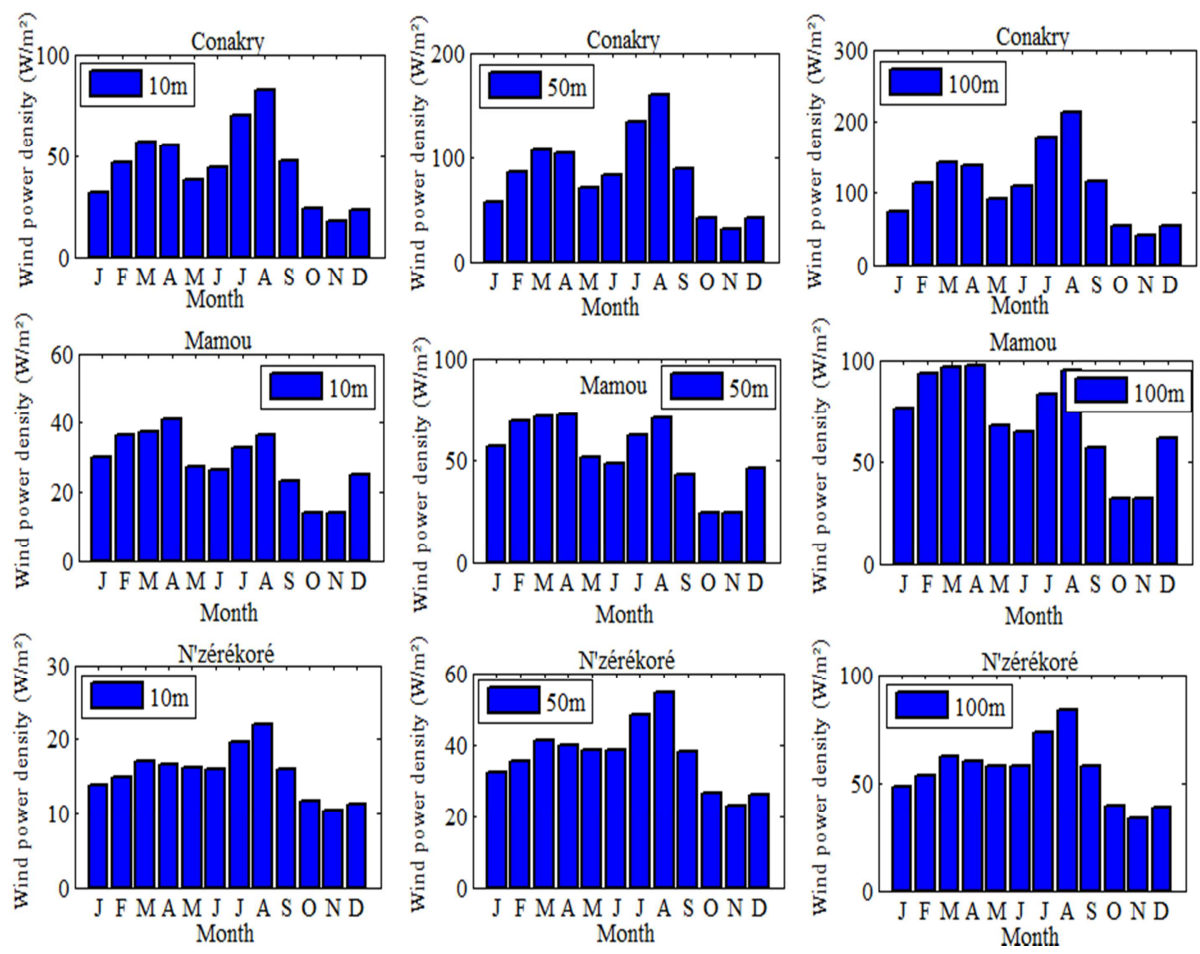

Figure 8. Variation of the wind power density at the three sites.

The quantities of energy recoverable at the site of Conakry vary from one month to another. We can note two peaks on this site. The first peak reached in March-April is less perceptible than the second. It is evaluated at $56 \mathrm{~W} \cdot \mathrm{m}^{-2}$ at 10 $\mathrm{m} ; 105 \mathrm{~W} \cdot \mathrm{m}^{-2}$ at $50 \mathrm{~m}$ and $140 \mathrm{~W} \cdot \mathrm{m}^{-2}$ at $100 \mathrm{~m}$. The second peak is observed in August and is around $82.65 \mathrm{~W} . \mathrm{m}^{-2}$ at 10 $\mathrm{m} ; 159.76 \mathrm{~W} . \mathrm{m}^{-2}$ at $50 \mathrm{~m} ; 213 \mathrm{~W} \cdot \mathrm{m}^{-2}$ at $100 \mathrm{~m}$. The lowest power densities observed are evaluated during the period from October to December. This densities vary from 17.74 W. $\mathrm{m}^{-2}$ in November to $23.64 \mathrm{~W} . \mathrm{m}^{-2}$ in October at $10 \mathrm{~m}$, from $30.96 \mathrm{~W} . \mathrm{m}^{-2}$ (November) to $41.86 \mathrm{~W} . \mathrm{m}^{-2}$ (October) at $50 \mathrm{~m}$ and from 39.9477 W.m ${ }^{-2}$ (November) to 54.62 W.m ${ }^{-2}$ (October) at $100 \mathrm{~m}$. The average annual power density obtained in Conakry is estimated at $45.77 \mathrm{~W} \cdot \mathrm{m}^{-2}$ at $10 \mathrm{~m}$; $85.62 \mathrm{~W} . \mathrm{m}^{-2}$ at $50 \mathrm{~m}$ and $113.31 \mathrm{~W} . \mathrm{m}^{-2}$ at $100 \mathrm{~m}$. At the site of Mamou, the largest quantities of energy are observed during the period of February, March, April and August. The average values obtained over this period are estimated at
$37.89 \mathrm{~W} . \mathrm{m}^{-2}$ at $10 \mathrm{~m} ; 71.18 \mathrm{~W} \cdot \mathrm{m}^{-2}$ at $50 \mathrm{~m}$ and $95.5 \mathrm{~W} \cdot \mathrm{m}^{-2}$ at $100 \mathrm{~m}$. The lowest quantities of energy are obtained during the period from October to November with average values of the order of $13.91 \mathrm{~W} \cdot \mathrm{m}^{-2}$ at $10 \mathrm{~m} ; 24.65 \mathrm{~W} \cdot \mathrm{m}^{-2}$ at $50 \mathrm{~m}$ and $32.17 \mathrm{~W} . \mathrm{m}^{-2}$. The average annual power density obtained at Mamou at the altitudes of $10 \mathrm{~m} ; 50 \mathrm{~m} ; 100 \mathrm{~m}$ is evaluated respectively at $28.29 \mathrm{~W} . \mathrm{m}^{-2} ; 52.83 \mathrm{~W} . \mathrm{m}^{-2} ; 70.42 \mathrm{~W} . \mathrm{m}^{-2}$. In N'zérékoré, the densities observed are lower than those obtained at the first two sites. The quantities of energy obtained from January to June are estimated in average at 16.12 W.m $\mathrm{m}^{-2}$ at $10 \mathrm{~m} ; 38.57 \mathrm{~W} . \mathrm{m}^{-2}$ and $58 \mathrm{~W} \cdot \mathrm{m}^{-2}$ at $100 \mathrm{~m}$. The peak recorded on this site is observed in August $(21.90$ W.m $\mathrm{m}^{-2}$ at $10 \mathrm{~m} ; 54.62 \mathrm{~W} . \mathrm{m}^{-2}$ at $50 \mathrm{~m}$ and $83.64 \mathrm{~W} \cdot \mathrm{m}^{-2}$ at 100 $\mathrm{m})$. The average annual power density is of $15.62 \mathrm{~W} \cdot \mathrm{m}^{-2}$ at 10 $\mathrm{m} ; 37.31 \mathrm{~W} . \mathrm{m}^{-2}$ at $50 \mathrm{~m} ; 56.13 \mathrm{~W} . \mathrm{m}^{-2}$ at $100 \mathrm{~m}$. The power density values obtained in this study have been compared with those obtained on some similar sites, in particulary in Côte d'Ivoire, Chad, Burkina Faso, Senegal, Ghana, Benin, 
Togo and Nigeria. The results obtained in the Ivory Coast more precisely in Korhogo in the northern savannah zone and reported by the studies of Boro et al. [33] indicates that the highest monthly wind potential is recorded in May and estimated at $29.28 \mathrm{~W} . \mathrm{m}^{-2}$ at $10 \mathrm{~m}$. On the Bobo-Dioulasso site in Burkina Faso, the annual wind potential is estimated at $53.13 \mathrm{~W} . \mathrm{m}^{-2}$ at $20 \mathrm{~m}$ and $84.05 \mathrm{~W} . \mathrm{m}^{-2}$ at $50 \mathrm{~m}$ according to the studies of Boro et al. [33]. Several sites in Chad have been the subject of the wind potential study [31]. The annual power densities obtained in Abéché, Am'Timan, Ati, Bokoro, Bousso, Doba, Faya-Largeau, Mao, Mongo, Moundou, N'Djamena, Pala and Sarh in Chad are respectively estimated at $68.80 \mathrm{~W} . \mathrm{m}^{-2} ; 8.04 \mathrm{~W} . \mathrm{m}^{-2} ; 10.06 \mathrm{~W} . \mathrm{m}^{-2} ; 12.21 \mathrm{~W} . \mathrm{m}^{-2} ; 6.73$ W.m ${ }^{-2} ; 26.03$ W.m ${ }^{-2} ; 45.29$ W.m ${ }^{-2} ; 24.07$ W.m ${ }^{-2} ; 50.54$ W.m ${ }^{-2}$; 31.41 W.m $\mathrm{m}^{-2} ; 64.63 \mathrm{~W} . \mathrm{m}^{-2} ; 54.80 \mathrm{~W} . \mathrm{m}^{-2} ; 16.58 \mathrm{~W} . \mathrm{m}^{-2}$ at $10 \mathrm{~m}$ On the coastal sites of Adafoah, Accra, Anloga, Aplaku, Mankoadze, Oshiyie, Warabeba in Ghana, Kayar, Potou, Gandon, Botla, Dara Andal, Nguebeul, Sakhor in Senegal, Lomé in Togo, Cotonou in Benin, Calabar, Uyo and Warri in Nigeria, the annual wind potential has been the subject of several studies in the works of $\mathrm{Na}$ and $\mathrm{Ka}$, Adaramola et al., Salami et al., Youm et al., Ouldbilal et al., Ouldbilal et al., Donnou et al. [34, 35, 36, 37, 38, 39, 40]. The power densities recorded on these sites are evaluated respectively at 174.86 W.m ${ }^{-2}$ at $12 \mathrm{~m} ; 97.75$ W.m ${ }^{-2}, 107.19$ W.m ${ }^{-2}, 105.19$ W.m ${ }^{-2} 98.04 \mathrm{~W} . \mathrm{m}^{-2}, 61.10 \mathrm{~W} \cdot \mathrm{m}^{-2}$ and $78.46 \mathrm{~W} . \mathrm{m}^{-2}$ at $10 \mathrm{~m}$ on the sites in Ghana. On the sites in Senegal the potential is evaluated respectively at $99.64 \mathrm{~W} . \mathrm{m}^{-2}, 145.30 \mathrm{~W} \cdot \mathrm{m}^{-2}, 103.14$ $\mathrm{W} . \mathrm{m}^{-2}$ at $20 \mathrm{~m}$ and $128.59 \mathrm{~W} . \mathrm{m}^{-2}, 107.74 \mathrm{~W} . \mathrm{m}^{-2}, 106.61$ W. $\mathrm{m}^{-2}$ and $117.53 \mathrm{~W} . \mathrm{m}^{-2}$ at $10 \mathrm{~m}$. In Togo it is estimated at $64.52 \mathrm{~W} . \mathrm{m}^{-2}$ at $10 \mathrm{~m}$ and $130.41 \mathrm{~W} . \mathrm{m}^{-2}$ at $50 \mathrm{~m}$. In Benin the density of wind power is estimated at $131 \mathrm{~W} \cdot \mathrm{m}^{-2}$ at $10 \mathrm{~m}$ and $332.67 \mathrm{~W} . \mathrm{m}^{-2}$ at $60 \mathrm{~m}$. Finally in Nigeria, it is respectively of order of $21.4 \mathrm{~W} . \mathrm{m}^{-2}, 48.9 \mathrm{~W} . \mathrm{m}^{-2}$ and $23.6 \mathrm{~W} . \mathrm{m}^{-2}$ at $10 \mathrm{~m}$. These different values obtained, especially those on the coast area, show that the potential obtained on the coastal site of Conakry is low. This observation could be explained by the hypothesis of the neutrality of the atmosphere made beforehand in this study and which would be the cause of the low values of power densities obtained for this coastal site. For the site of Mamou which is not a coastal site, the values observed are higher than the values on some sites in Chad such as Am'Timan, Ati, Bokoro, Bousso, Doba, Mao, Sarh and lower on the other sites. In N'zérékoré the potential obtained is higher than that obtained in Am'Timan, Ati, Bokoro, Bousso in Chad.

In the studies of $\mathrm{Na}$ and $\mathrm{Ka}$ [34], the different classes of power density that allow to define the type of wind installation adapted to a site have been reported. For class 1 where the power densities vary from 0 to $200 \mathrm{~W} . \mathrm{m}^{-2}$ for an altitude greater than $10 \mathrm{~m}$, the standard believes that the large-scale exploitation of wind energy on these sites is not suitable. In view of the results obtained in this study, we can therefore conclude that, under a neutral atmosphere, only the Conakry site could house a small-scale wind power installation. At the sites of Mamou and N'zérékoré where the wind are lower, the pumping water from multi-blade wind turbines could be considered.

\section{Conclusion}

The vertical profile of winds has been determined in this study by extrapolation of the wind speeds measured at $10 \mathrm{~m}$ above the ground using the power law under a neutral atmosphere. Then, the wind energy potential was studied between $10 \mathrm{~m}$ and $100 \mathrm{~m}$ of altitude in order to characterize each site. The results obtained show the following:

(1) The Conakry site is the windiest of the three study sites with an average speed estimated at $2.83 \mathrm{~m} . \mathrm{s}^{-1}$ at $10 \mathrm{~m}$ and $4.23 \mathrm{~m} . \mathrm{s}^{-1}$ at $100 \mathrm{~m}$.

(2) The variation of the Weibull parameters indicates that these two parameters are increasing functions of the altitude and their highest values are observed for the windiest periods. These parameters vary from 1 to 1.8 for the k parameter and from 1.5 to $6 \mathrm{~m} \cdot \mathrm{s}^{-1}$ for the scale parameter.

(3) The quantities of energy collected on the three sites indicate that only the Conakry site could be shelter a small-scale installations for the production of wind-generated electrical energy. The average annual density is respectively estimated at 45.77 W.m ${ }^{-2} ; 85.62$ W. $\mathrm{m}^{-2}$ at $50 \mathrm{~m}$ and $113.31 \mathrm{~W} . \mathrm{m}^{-2}$ at $100 \mathrm{~m}$. On the other two sites, the pumping water from the multi-blade wind turbines could be considered.

\section{Nomenclature}

$V_{h}$ Wind speed at the hub height of wind turbine

$V_{l}$ Wind speed at $10 \mathrm{~m}$ above the ground

$Z_{h}$ Hub height of wind turbine

$Z_{1}$ Altitude of $10 \mathrm{~m}$

$\alpha$ Shear coefficient of wind

$\rho$ Density of the flow

c Scale parameter of Weibull

$\mathrm{k}$ shape parameter of Weibull

$\overline{\mathrm{V}}$ Average wind

$\Gamma$ Gamma function

$\mathrm{P}$ Wind power density

\section{Acknowledgements}

The authors of this paper sincerely thank the Guinean national weather direction for having made the wind data available to them, which were used to carry out this research work

\section{References}

[1] Global Wind Energy Council (2017), http://gwec.net/wpcontent/uploads/2018/02/Global_Cumulativ e_Installed_Wind_Capacity_2001-2017.Jpg.

[2] G. P. van den Berg, "Wind turbine power and sound in relation to atmospheric stability," Wind Energy, vol. 11, no. 2, pp. 151169, 2008. 
[3] L. Morales, F. Lang, and C. Mattar, "Mesoscale wind speed simulation using CALMET model and reanalysis information: an application to wind potential," Renewable Energy, vol. 48, pp. 57-71, 2012.

[4] J. F. Manwell, J. G. McGowan and A. L. Rogers, “Wind energy explained", John Wiley and Sons Ltd. 2003.

[5] M. R Elkinton, A. L. Rogers and J. G. McGowan, (2006) “An investigation of wind-shear models and experimental data trends for different terrains", WinEn, 30 (4), pp 341-350, 2006.

[6] G. Gualtieri and S. Secci, "Methods to extrapolate wind resource to the turbine hub height based on power law: a 1-h wind speed vs. weibull distribution extrapolation comparison", Renew. Energy, 143, pp 183-200, 2012.

[7] S. Emeis, "Wind energy meteorology, atmospheric physics for wind power generation”. Berlin: Springer. 978-3-642-30522-1, 2013.

[8] D. Khalfa, A. Benretem, L. Herous, I. and Meghlaoui, I., "Evaluation of the adequacy of the wind speed extrapolation laws for two different roughness meteorological sites", Am. $J$. Appl. Sci., 11 (4), pp 570-583, 2014.

[9] M. Sedghi, M. Boroushaki, and S. K. Hannani, "Modeling changes in wind speed with height in iran's cities and its impact on the energy production" Journal of Renewable and Sustainable Energy, (7), pp 1-12, 2015

[10] C. Xu, C. Hao, L. L. X. Han, F. Xue, M. Sun and W. Shen, "Evaluation of the power-law wind-speed extrapolation method with atmospheric stability classification methods for flows over different terrain types", Appl. Sci., (8), pp 1-16, 2018.

[11] C. A Lopez-Villalobos., O. R. Rodriguez-Hernandez, Campos-Amezcua, G. Hernandez-Cruz, O. A. Jaramillo and J. L. Mendoza, "Wind turbulence intensity at la ventosa, mexico: a comparative study with the IEC 61400 standards", Energies, (11), pp 1-19, 2018.

[12] G. Grassi and P. Vecchio, "Wind energy prediction using a two-hidden layer neural network," Communications in Nonlinear Science and Numerical Simulation, vol. 15, no. 9, pp 2262-2266, 2010.

[13] C. G. Justus and A. Mikhail, "Height variation of wind speed and wind distributions statistics," Geophysical Research Letters, vol. 3, no. 5, pp. 261-264, 1976.

[14] M. Schwartz and D. Elliott, "Towards a wind energy climatology at advanced turbine hub-heights," in Proceedings of 15th Conference on Applied Climatology, Savannah, GA, USA, May 2005.

[15] M. A. Lackner, A. L. Rogers, J. F. Manwell, and J. G. McGowan, "A new method for improved hub height mean wind speed estimates using short-term hub height data", Renew. Energy, 35, pp 2340-2347, 2010.

[16] M. E. Okorie, F. Inambao and Z. Chiguvare, "Evaluation of wind shear coefficients surface 645 roughness and energy yields over inland locations in namibia", Procedia Manuf, (7), pp 630-638, 2017.

[17] D. Elliott, J. Cadogan, "Effect of wind shear and turbulence on wind turbine power curves". In: Proceedings of the 1990 European community wind energy conference, Madrid, Spain,

$$
\text { p. } 79-83,1990 .
$$

[18] P. Gardner, A. Garrad, P. Jamieson, H. Snodin, and G. Nicholls, "Wind Energy, The Facts, An Analysis of Wind Energy in theEU-25", vol. 1, European Wind Energy Association, Bruxelles, Belgium, 2002.

[19] F. Banuelos-Ruedas, C. Angeles-Camacho, S. Rios-Marcuello, "Analysis and validation of the methodology used in the extrapolation of wind speed data at different heights", Renewable and Sustainable Energy Reviews, 14, pp 2383-2391, 2010.

[20] S. M. Boudia, "Optimisation de l'évaluation temporelle du gisement énergétique éolien par simulation numérique et contribution à la réactualisation de l'atlas des vents en Algérie, Thèse de Doctorat, Université de Tlemcen Abou Bakr Bleka”1d, Tlemcen, Algeria, 2012.

[21] B. A. H. Maadjou, "Point Focal National CBD. Rapport sur la mise en œuvre du programme sur la biodiversité marine et côtière".

[22] GUINEA-SCN. Ministère de l'environnement, des eaux et forêts: Seconde communication nationale à la convention cadre des Nations Unies sur le changement climatique, page 2, Conakry, 2018.

[23] C. G. Justus, W. R. Hargraves, A. Mikhail and D. Graber, "Methods for Estimating Wind Speed Frequency Distributions", Journal of Applied Meteorology, 17 (3), PP 350-53, 1978 .

[24] G. Hellman, "Uber die Bewegung der Luft in den untersten Schichten der Atmosphere", Meteorol Z., 34, pp 273-285, 1916.

[25] D. A. Spera and T. R. Richards, "Modified power law equations for vertical wind profiles. In: Conference and workshop on wind energy characteristics and wind energy siting", Portland OR, USA. 1-10, 1979.

[26] S. Kulkarni and H. P. Huang, "Changes in Surface Wind Speed over North America from CMIP5 Model Projections and Implications for Wind Energy", Advances in Meteorology, Article ID 292768, pp 1-10, 2014.

[27] G. Gualtieri and S. Secci, "Wind shear coefficients, roughness, length and energy yield over coastal locations in Southern Italy", Renew. Energy, 36 (3), pp 1081-1094, 2011.

[28] B. Ould Bilal. Etude et modélisation du potentiel éolien du site de Gandon à Saint Louis: application au dimensionnement d'une éolienne adaptée au site, Mémoire de Master, ESP, Université Cheikh Anta Diop (UCAD), 2005.

[29] R. O. Fagbenle, J. Katende, O. O. Ajayi and J. O. Okeniyi, "Assessment of wind energy potential of two sites in North-East, Nigeria”, Renewable Energy, 36 (4), pp 1277-1283, 2011.

[30] A. A. Akinsanola, K. O. Ogunjobi, A. T. Abolude, S. C. Sarris and K. O. Ladipo, K., "Assessment of Wind Energy Potential for Small Communities in South-South Nigeria: Case Study of Koluama, Bayelsa State", J Fundam Renewable Energy Appl, 7 (2), pp 1-6, 2017.

[31] D. H. Didane, N. Rosly, M. F. Zulkafli and S. S. Shamsudin "Evaluation of Wind Energy Potential as a Power Generation Source in Chad". International Journal of Rotating Machinery, 2017, Article ID: https://doi.org/10.1155/2017/3121875, 2017. 
[32] A. S. A. Ajavon, A. A. Salami, M. K. Kodjo, K. Bédja, "Comparative characterization study of the variability of wind energy potential by wind direction sectors for three coastal sites in Lomé, Accra and Cotonou", Journal of Power Technologies, 95 (2), pp 134-142, 2015.

[33] D. Boro, H. E. V. Donnou, I. Kossi, N. Bado, F. P. Kieno and J. Bathiebo, "Vertical Profile of Wind Speed in the Atmospheric Boundary Layer and Assessment of Wind Resource on the Bobo Dioulasso Site in Burkina Faso", Smart Grid and Renewable Energy, 10, pp 257-278, 2019.

[34] U. A. O. Na, I. and Ka, "Investigation of Wind Power Potential over Some Selected Coastal Cities in Nigeria". Innovative Energy \& Research, 6, 1, pp 1-12, 2017.

[35] M. S. Adaramola, M. Agelin-Chaab, S. S. Paul, "Assessment of wind power generation along the coast of Ghana", Energy Conversion and Management, 77, pp 61-69, 2014.

[36] A. A. Salami, A. S. A. Ajavon, K. Mawugno, M. K. Kodjo, and K. Bédja., "Evaluation of wind Potential for an Optimum Choice of Wind Turbine Generator on the sites of Lomé, Accra and Cotonou Located in the Gulf of Guinea", Int. Journal of Renewable Energy Development 5 (3), pp 211-233, 2016.

[37] I. Youm, J. Sarr, M. Sall, A. Ndiaye and M. M. Kane, "Analysis of wind data and wind energy potential along the northern coast of Senegal”, Rev. Energ. Ren, 8 (2), pp 95-108, 2005.

[38] B. Ouldbilal, M. Ndongo, C. M. F. Kebe, V. Sambou and P. A. Ndiaye,"Feasibility study of wind energy potential for electricity genaration in the northwestern coast of Senegal", Energy Procedia, 36, pp 1119-1129, 2013.

[39] B. Ouldbilal, M. Ndongo., V. Sambou, P. A. Ndiaye and C. M. Kebe, "Diurnal characteristics of the wind potential along the northwestern coast of Senegal", International Journal of the Physical Sciences, 6 (35), pp 7950-7960, 2011.

[40] H. E. V. Donnou, A. B. Akpo, G. F. Nonfodji and B. B. Kounouhewa, "Variability of Onshore Wind Energy Potential in the $60 \mathrm{~m}$ above the Ground under Convective Atmosphere in Southern Benin." American Journal of Energy Research, vol. 7 , no. 1, pp 19-30 doi: 10.12691/ajer-7-1-3. 2019. 